\title{
Hysteroscopic sterilization with occlusion of sheep uterine tube using n-butyl-2-cyanoacrylate adhesive ${ }^{1}$
}

\author{
Esterilização histeroscópica com oclusão da tuba uterina de ovelha \\ com adesivo de n-butil-2-cianoacrilato
}

\author{
Sergio Bigolin², Djalma José Fagundes ${ }^{3}$, Henri Chaplin Rivoire ${ }^{4}$, Anna Tereza Negrini Fagundes ${ }^{5}$, Ricardo Simões ${ }^{6}$, \\ Manuel de Jesus Simões ${ }^{7}$ \\ 1. Research performed at Surgery and Experimentation Pos-Graduate Program, Operative Technique and Experimental Surgery Division, Department \\ of Surgery, Federal University of São Paulo (UNIFESP), Brazil. \\ 2. Master, Assistant Professor, Division of Gynecology, Regional Integrated University of High Uruguay and Missions (Campus Erechim), Rio Grande \\ do Sul, Brazil. \\ 3. PhD, Associate Professor, Division of Operative Technique and Experimental Surgery, Department of Surgery, UNIFESP, São Paulo, Brazil. \\ 4. PhD, Head of Surgery Department of Foundation University of Rio Grande (FURG), Rio Grande do Sul, Brazil. \\ 5. Medical Student, Santo Amaro University (UNISA), São Paulo, Brazil. \\ 6. Medical Student, UNIFESP, São Paulo, Brazil. \\ 7. Full Professor, Head Division of Histology and Structural Biology, Department of Morphology, UNIFESP, São Paulo, Brazil.
}

\begin{abstract}
Purpose: To evaluate the fertility and analyze the macroscopic, microscopic and morphometric aspects of sheep uterine tube sterilization with a hysteroscopically insert of n-butyl-2-cyanoacrylate adhesive. Methods: 12 adult sheep, with one previous pregnancy, were distributed as follows: group $\mathrm{L}(\mathrm{n}=3)$ subjected to laparotomy and Pomeroy uterine tube ligation, group $S(n=3)$ subjected to hysteroscopic application of saline solution in tube isthmus and group $A D(n=6)$, that was subjected to hysteroscopic application of $0.5 \mathrm{ml}$ of n-2-butil-cyanoacrylate in tube isthmus. They were mated with fertile males for ninety days. The non pregnant sheep, at the 90th day, were subjected to laparotomy with uterus and tubes uterine resection. The fragments of uterine tubes were fixated in 10\% formalin and processes for histology evaluated, and slices dyes for H.E. Data were evaluated by Wilcoxon and Mann-Whitney and Fisher's exact test. Results: All sheep from groups $\mathrm{L}$ and $\mathrm{AD}$ did not get pregnant ( $0 \%)$ in contrast with sheep from group S (100\%); the adhesive remained integral in the uterine tube lumen. The percentual of adherences $(66.6 \%)$ and fibrosis responses (100\%) was significantly higher in the group $\mathrm{L}$ than group $\mathrm{AD}(0 \%)(\mathrm{p} \leq 0.01)$. The diameter of the caudal tube in group $\mathrm{AD}(2652.15 \pm 45.76 \mu \mathrm{m})$ was significantly wider than that of the group L $\left(1868.27 \pm 56.11^{*} \mu \mathrm{m}\right)(\mathrm{p} \leq 0.05)$. Conclusion: The hysteroscopic insertion of cyanoacrylate in the uterine tube lumen of sheep was effective to obstruct the uterine tube and to promote the sterilization. Key Words: Fallopian Tubes. Sterilization, Reproductive. Tissue Adhesives. Sheep.
\end{abstract}

\section{RESUMO}

Objetivo: Avaliar a fertilidade e aspectos macroscópicos, microscópicos e morfométricos da esterilização histeroscópica de tubas uterinas de ovelhas com o adesivo de n-butil-2-cianoacrilato. Métodos: 12 ovelhas adultas, com uma prenhez anterior, foram distribuídas como segue: o grupo L $(n=3)$ submetidas à laparotomia e laqueadura tipo Pomeroy, grupo S (n=3) submetidas à aplicação histeroscópica de solução salina no istmo tubário e grupo AD (n=6), com aplicação histeroscópica de $0,5 \mathrm{ml}$ de cianoacrilato. As ovelhas foram acasaladas com machos de comprovada fertilidade por noventa dias. As ovelhas não prenhes aos 90 dias, foram submetidas à laparotomia com ressecção do útero e tubas uterinas, que foram fixadas em formalina $10 \%$ s e os cortes histológicos corados em hematoxilina/eosina. Os resultados foram avaliados pelo teste de Wilcoxon e teste exato de Fisher. Resultados: Todas as ovelhas dos grupos L e AD não ficaram prenhes ( $0 \%$ ) ao contrário das ovelhas do grupo S (100\%); o adesivo permaneceu íntegro no lúmen tubário. O percentual de aderências $(66.6 \%)$ e de fibrose $(100 \%)$ foi significativamente maior no grupo L do que no grupo AD ( $0 \%)(\mathrm{p} \leq 0,01)$. O diâmetro da porção caudal no grupo AD $(2652,15 \pm 45,76 \mu \mathrm{m})$ foi significativamente maior do que grupo L $(1868,27 \pm 56.11 \mu \mathrm{m})$ $(\mathrm{p} \leq 0,05)$. Conclusão: A inserção histeroscópica do cianoacrilato no lúmen tubário de ovelhas foi eficaz para obstruir a tuba uterina e promover a esterilização.

Descritores: Tubas uterinas. Esterilização Reprodutiva. Adesivos Teciduais. Ovinos. 


\section{Introduction}

Uterine tube sterilization is the most common contraception method used on family planning in the wideworld1. Every year in the United States, 750 thousands women were submitted to the laparotomy tubal sterilization 2. Other countries as Brazil are following this tendency3, where forty percent of women between 15 and 49 years old underwent to this procedure, and $50-70 \%$ of them were submitted to this procedure during caesarian surgical (CS) delivery4. By the other hand, $88 \%$ of surgical sterilization is performed immediately after the last labor and $77 \%$ after caesarian section5. In Brazil, the laws regulating the women sterilization were approved in January 12th, 1996 (Federal law number $n^{\circ}$ 9.263) allowing women aged above 25 years, having two or more children (alive), to choose the procedure in the interval delivery period 5 . Since then, we could observe an increase in the number of female sterilizations from 293 in 1996 up to 15,370 in 2001 5. In some Brazilian cities, such as São Paulo, Curitiba, Palmas, Recife and Belo Horizonte, the rate of women who wish the sterilization is 25.8 to $36 \%$. However, only part of the population is subjected to a sterilization procedure 5. One explanation for the discrepancy of these data is the cost and the low rate of Public Health investments 4, 5. Therefore, the efforts by now are to developing new surgical procedures that could be performed in day surgery setting with low cost. Following this idea, the obstruction of uterine tube using hysteroscopic access could be an option. Some authors, using hysteroscopic access, have shown that the use of thermo-coagulation (electrical surgery and laser) and sclerosing substances (chemicals) for the tube sterilization are reliable. However, none of them were safe and effective enough to be used in large scale in our population 6-10. Many mechanical methods (ceramic, silicone) were used, but they are not effective as well 9,11. Nowadays there are two new mechanical devices, the Adiana Complete TransCervical Sterilization (Adiana, Redwood City, CA) and the Essure ${ }^{\circledR}$ (Conceptus, Inc., San Carlos, CA). Both of them, when inside the tube, induce the formation of granulomatosis tissue and a total occlusion within three months. These methods become more effectiveness as far as the hysteroscopic procedures are improving 10 . On the other hand, the adhesive of cyanoacrylate has been used in many ways for obstruction of digestive, urinary or pulmonary fistulae 12-14. Some authors described the success of occlusion of human uterine tube 15, 16, however others have shown no effect at all 17-19. Notwithstanding, all of them have shown no complications with the procedure. The n-butyl cyanoacrylate formulation has shown better adhesivity than that engineered with n-methyl cyanoacrylate that is often used. In view of the controversies in the literature regarding the sterilization methods, we were prone to study the effect of an n-butyl-2-cyanoacrylate technique of sterilization using the hysteroscopic access.

\section{Methods}

This study had the approval of the Medical Ethic Committee of the Federal University of São Paulo-Escola Paulista de Medicina ( $n^{\circ}$ 1352/04) and Research BioEthical Committee of Universidade Regional Integrada do Alto Uruguay e Missões (Campus Erechim) (n 160-1/ PIA/04). Twelve adult (3 yr-old), female Texel sheep, weighing in the range 50-60 kg were studied. All of them with one previous pregnancy were randomly allocated in 3 groups as follows: Group L (surgical ligation, $n=3$ ); Group $\mathrm{S}$ (sham, $\mathrm{n}=3$ ) and Group AD(adhesive patch, $\mathrm{n}=6$ ). The sheep were maintained on a 12:12 h dark:light cycle, under controlled temperature and humidity conditions. The manipulation of the animals was performed following the Brazilian animals care protocol and special care was taken to minimize animals suffering and to set the number of animals to a minimum required. The animals were fed a normal sheep chow and had free access to tap water. An anesthetic protocol was applied prior to surgery with an association of xylazine $(0.2 \mathrm{mg} . \mathrm{Kg}-1)$ and tiletamine/ zolazepam (3mg.Kg-1) intramuscularly (i.m). The animals received prophylactic antibiotic therapy with ampicillin (20mg.Kg-1). The sheep of group L underwent a surgical procedure following the Pomeroy protocols 20, as outlined briefly below. Under aseptic and anesthetic conditions, an infra-umbilical incision $(10 \mathrm{~cm})$ was realized with exposition of the abdominal cavity and identification of the isthmus of both uterine tubes. After the identification, the tubes were obstructed by with double catgut suture and resection of $1 \mathrm{~cm}$ of each tube between the sutures. Then, the abdominal cavity was properly sutured. The animals of groups $\mathrm{S}$ and $\mathrm{AD}$, after anesthesia, were positioned in ventral decubitus and hysteroscope ( $4 \mathrm{~mm} / 30^{\circ}$ scope) connected to a insufflator and a xenon light $(300 \mathrm{~W})$ were the equipment used to start the procedure. A vaginal speculum was placed for the identification of the uterine cervix. Then, it was grasped and pulled to visualize the external orifice of the uterus cervix. The cervical opening and uterus cavity were insufflated with carbon dioxide (CO2) in a rate of $50 \mathrm{ml} / \mathrm{min}$ at a pressure of $60 \mathrm{mmHg}$. Through the hysteroscope, the right and left ostia of the uterus were identified and an urethral catheter (5Fr) with scale of $1 \mathrm{~cm}$ on it was used, allowing the correct positioning in the tube for the delivery of $0.5 \mathrm{ml}$ of saline fluid (group S) or $0.5 \mathrm{ml}$ of n-bytil-2-cyanocrylate (group AD) at both uterine tubes. Thereafter the instruments were removed and the animals were monitored during about 2 hours for the anesthetic recovering period. After 14 days of surgery, all animals were grouped with surely fertile male for 90 days and then were examined for signs of pregnancy. The non-pregnant animals were euthanized by the carotid cutting method and upon laparoscopy were further examined as to the presence of adherences or abscesses. The uterus and uterine tubes were removed and processed for microscopic analyses. Three areas were analyzed, as follows: 1st, the part where 
uterine tube occlusion was done by suture or adhesive patch; 2 nd and 3rd, two peaces of the tube $1 \mathrm{~cm}$ away from the occlusion site (from each side). These tissues were immersed in $10 \%$ formaldehyde for $24 \mathrm{~h}$ and processed for inclusion in paraffin, sectioned in $5 \mu \mathrm{m}$-slices and stained for hematoxilin/eosin (HE) for morphological analyses.

\section{Quantitative analysis}

The quantitative analyses were performed for the presence or absence of granuloma and the measurements $(\mu \mathrm{m})$ of the uterine diameter, and of the mucosa and smooth muscle layer thickness. The morphometric imaginings of the uterine tube were captured with a digital camera (AxioCam MRc, Zeiss) attached to a light microscope (Axioplan, Zeiss) and further analyzed by Axiovision Rel 4.2 (Carl Zeiss) program. Each animal had a mean of 8 measurements in all portions analyzed in the uterine tube. Statistical analysis Data were analyzed by Wilcoxon and Mann-Whitney tests for comparing the differences among the groups. Also, we used the Fisher's exact test to compare the proportions of adherences or granulomatosis presence among the groups. The level $\mathrm{P} \leq 0.05$ was considered to be significant.

\section{Results}

\section{Fertility}

The animals of the group S (Sham) became pregnant during the 90-day period of mating and had healthy term pups. All animals were left alive. The animals which had tube ligation by suturing procedure (group L) or by adhesive with n-bytil-2-cyanoacrylate (group AD) have not become pregnant during the study. Besides they shared the same fertile males which were able to get pregnant the females of group S (Table 1). Macroscopic analysis The animals which had a Pomeroy ligation tube (group L) for occlusion of the uterine tube showed the presence of granulomatosis response in $100 \%$ for the suture material applied (Table 1) (Figure 1), and adherences in $66.6 \%$. The group using the adhesive patch (group AD), we observed an increase in diameter of the most caudal portions of the tubes (Figure 2).

TABLE 1 - Percentual (\%) of pregnancy, adherence and granulomatosis responses depending upon the tubal intervention technique used: Pomeroy tube ligation (group L), n-bytil-2-cyanoacrylate-containing adhesive patch (group AD) or physiologic saline (group S) (see Methods)

\begin{tabular}{|c|c|c|c|c|c|c|}
\hline & \multicolumn{6}{|c|}{ Experimental groups } \\
\hline & \multicolumn{2}{|c|}{ S (sham) } & \multicolumn{2}{|c|}{ L (ligation) } & \multicolumn{2}{|c|}{ AD (adhesive patch) } \\
\hline & Present & Absent & Present & Absent & Present & Absent \\
\hline Pregnancies & 100 & 0 & 0 & 100 & 0 & 100 \\
\hline Adherences & - & 一 & $66.6^{*}$ & 33.3 & 0 & 100 \\
\hline Granulomatosis responses & - & - & $100 *$ & 0 & 0 & 100 \\
\hline
\end{tabular}

* $\mathrm{P} \leq 0.01$ compared to Sham and Adhesive groups (Fisher exact test).

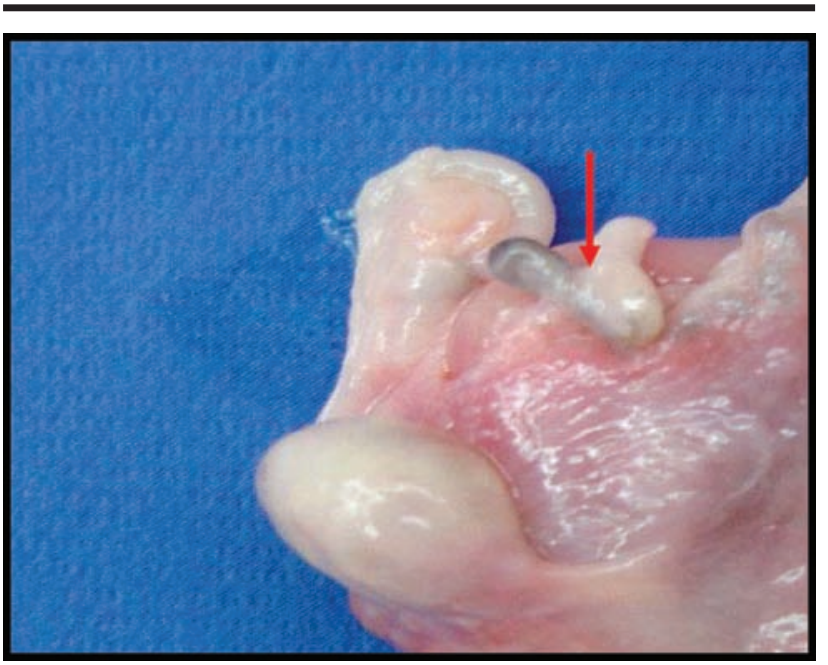

FIGURE 1 - Photograph of a typical uterine tube using the Pomeroy occlusion technique (group L) and granulomatosis tissue formation (arrow) (20X)

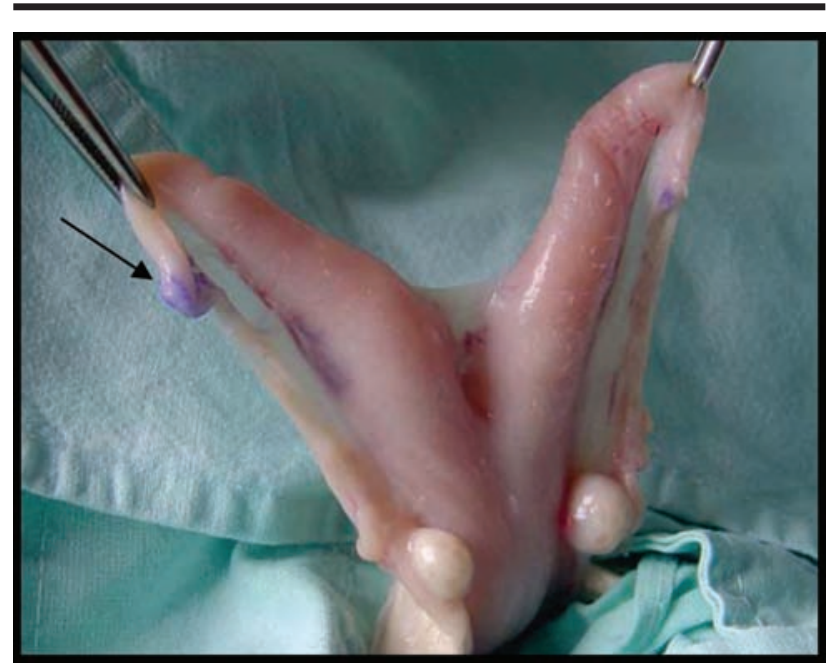

FIGURE 2 - Photograph of a typical uterine tube of group AD. Notice the presence of adhesive patch (arrow) and difference in diameter among the different portions of the tube (20X) 


\section{Microscopic analysis}

The group $\mathrm{L}$ and $\mathrm{AD}$ showed the same histological features. The most distal area of the tube or in the adhesive patch area had three distinct layers, namely, serosa, muscular and mucosa. The mucosa layer had a well-defined lamina propia with fewer projections into the luminal aspect of the tube. The epithelium was simple columnar and ciliary cells (Figures 3A, B). The most cranial part of the tube presented a dilated area with a well developed and folded mucosa (Figures 3E, F). The folding was constituted of connective tissue as a simple cylindrical ciliated epithelium. The group $\mathrm{L}$ showed a discontinuation of the tubal lumen and the presence of some local fibrosis and a granulomatosis response tissue (Figure $3 \mathrm{C}$ ). The group AD (adhesive) had a less developed response of the simple ciliated epithelium and lamina propria (Figure 3D). The presence of adhesive between with projections of mucosa was observed, with no signs of fragmentation or phagocytes (Figure 3D).

\section{Morphometric analysis}

We observed a significant increase between the cranial and caudal areas of the tube where we used the Pomeroy technique (group L) $(\mathrm{P} \leq 0.001)$. However, there were no differences regarding these areas in the group $\mathrm{AD}$. There was a significant increase in diameter of the tube in the group AD compared with group $\mathrm{L}(\mathrm{P} \leq 0.001)$ (Table 2$)$. The most cranial areas of the tube had not differences in diameter compared among the groups. There were no group differences in the mucosa and uterine tube thickness.

FIGURE 3 - Photomicrographs of the various portions of sheep uterine tube of two of the experimental groups. Inserts A, $\mathrm{C}$ and $\mathrm{E}$ correspond to the group L (Pomeroy ligation); inserts $\mathrm{B}, \mathrm{D}$ and $\mathrm{F}$ refer to the group AD(n-butyl-cyanoacrylatecontaining adhesive patch). A and $\mathrm{B}=$ caudal region of the tube; $\mathrm{C}=$ ligation region; $\mathrm{D}=$ patch implant region; $\mathrm{E}$ and $\mathrm{F}$ refer to the cranial portions of the tube. The arrows indicate mucosal projections (250 X). $\mathrm{R}=$ implant localization

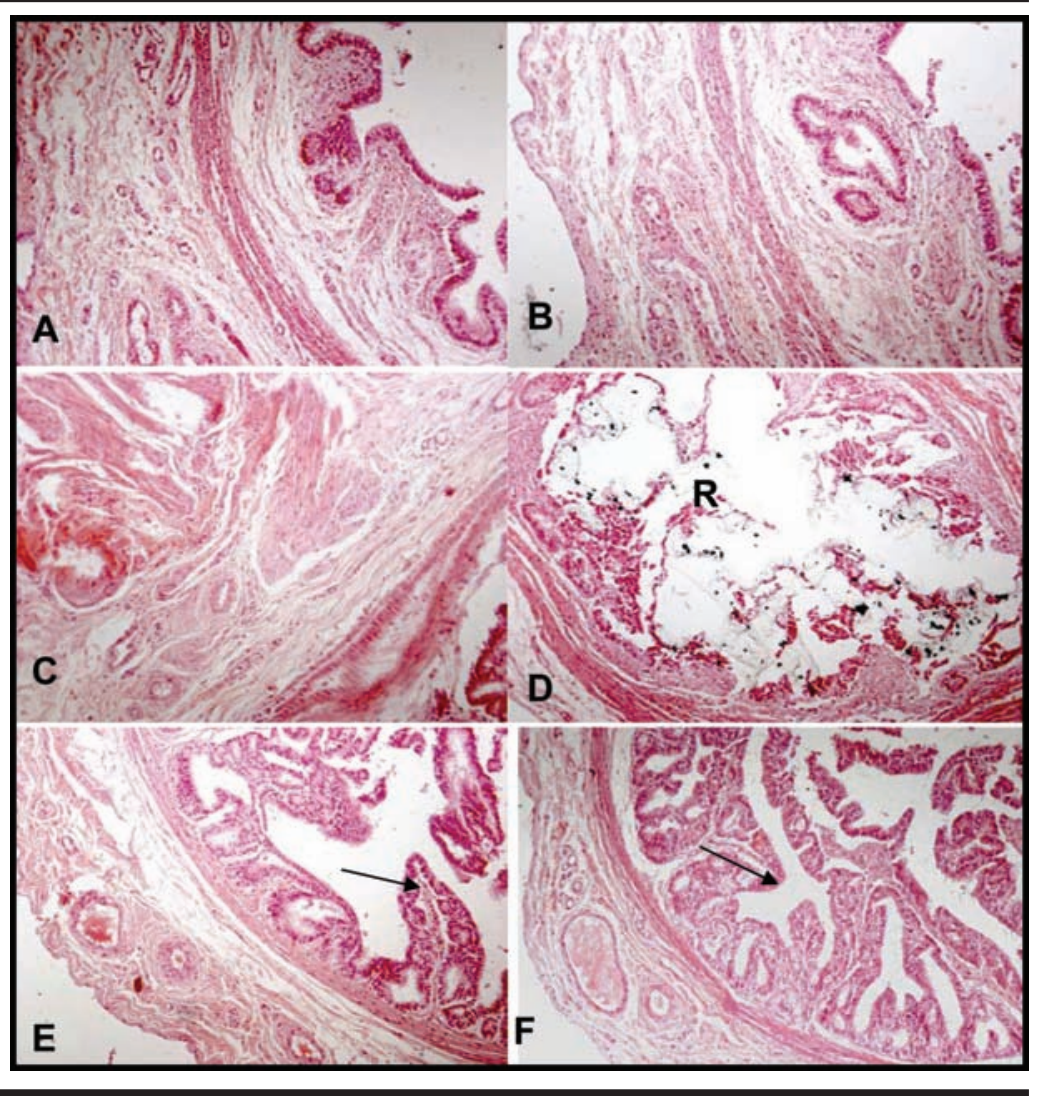

TABLE 2 - Hystomorphometric data (expressed as mean \pm SD) of tube diameter measurements, mucosal and smooth muscular layer thickness of three distinct regions of sheep uterine tubes in group L(Pomeroy ligation) and AD (n-butyl-cyanoacrylate-containing adhesive patch)

\begin{tabular}{|c|c|c|c|c|c|c|}
\hline \multirow[b]{2}{*}{ Regions } & \multicolumn{3}{|c|}{ Tube ligation - Pomeroy (L) } & \multicolumn{3}{|c|}{ Adhesive patch (AD) } \\
\hline & cranial & middle & caudal & cranial & middle & caudal \\
\hline Tubal diameter $(\mu \mathrm{m})$ & $2668.16 \pm 57.21^{\mathrm{c}}$ & $1831.02 \pm 47.12^{\mathrm{a}}$ & $1868.27 \pm 56.11^{\mathrm{a}}$ & $2585.37 \pm 66.7^{c}$ & $2411.12 \pm 37.35^{b}$ & $2652.15 \pm 45.76^{c}$ \\
\hline Mucosa thickness $(\mu \mathrm{m})$ & $84.12 \pm 15.78^{a}$ & $84.01 \pm 11.88^{a}$ & $81.31 \pm 10.12^{\mathrm{a}}$ & $82.32 \pm 23.14^{\mathrm{a}}$ & $96.24 \pm 11.51^{\mathrm{a}}$ & $83.01 \pm 18.91^{\mathrm{a}}$ \\
\hline $\begin{array}{l}\text { Smooth muscular } \\
\text { layer thickness }(\mu \mathrm{m})\end{array}$ & $178 \pm 29.57^{\mathrm{a}}$ & $154 \pm 19.15^{a}$ & $147 \pm 25.17^{\mathrm{a}}$ & $169 \pm 21.53^{a}$ & $143 \pm 17.91^{\mathrm{a}}$ & $146.12 \pm 22.15^{\mathrm{a}}$ \\
\hline
\end{tabular}

$(\mathrm{a}<\mathrm{b}<\mathrm{c}, \mathrm{P}<0.05$, Wilcoxon test) 


\section{Discussion}

The surgical procedure for the female sterilization should be simple, cheap, and easily accessible 5 . In the present days, the hysteroscopy for uterine tube sterilization by transvaginal approach has been shown a low cost and less surgical intercurrences than the laparoscopy procedure $8,10,21$. However, the main controversy is on the safety and effectiveness device that should be inserted on the tube8,10, 21.Silicone implants, hydrogel dispositive, metallic embolus, endometrial ablation using laser, diode or radiofrequency, sclerosing substances or adherence fibrin did not prove to be safe for routine use 8, 21. Currently, the Essure ${ }^{\circledR}$ is the only dispositive approved by Food and Drug Administration (FDA) and the European Health Office (EHO) 2. The micro-inserts are a probe of metals (nickel-titanium and stainless steel) covered by polyester fibers which induce a local inflammatory response in the uterine tube 10. The four centimeters length of fibrosis area produced by Essure should be impairment for an eventual recanalization surgical procedure. On the other hand, the rate of tube sterilization regret is about $25 \%$ among the Brazilian women3,4 and the high costs of each proceeding (US\$1,370.00)21 became the method not feasible for the Brazil Public Health. The Adiana sterilization method produce thermal tube lesion, and consists of a radiofrequency (RF) generator, a delivery catheter, and an implantable matrix. The delivery catheter is introduced through the hysteroscope, their tip is positioned into the ostium of the uterine tube and the procedure is completed. The method is in the earlier phase of clinical appliance and the cost is too high because of special equipment needed 22. In this study, we intended to test the effectiveness of the n-bytil-2-cyanoacrylate adhesive as a procedure for tube obstruction known as a safe and effective method for obstruction of digestive, urinary and pulmonary fistulas 12-14. The studies are outdated about the application of cyanoacrylate adhesive for tube obstruction 23, 24 and the studies in humans are rather contradictory 16 . We observed that the use of n-bytil-2-cyanocrylate within sheep uterine tubes proved efficacious to obstruct the tubes in all animals of the group $\mathrm{AD}$ and rendered them sterile. The substance does not induce significant morphological changes, nor absorption of the adhesive patch was reported 12-14. Our data suggested that this technique may be safe as no side effects were observed on the obstructed sheep, and these findings are supported by data of other studies 6 , 7. In addition, as had shown by other report25 there was no problems related to fertility after the uterine and tubal hysteroscopic manipulations and saline solution introduction. The tube ligation group (group L) presented many local adherences around the surgical area. This side effect occurred in $66.6 \%$ of the tubes in group L, being the tubes in group $\mathrm{AD}$ free of adherences $(0 \%$ cases). Regardless the controversy, some authors have considered the adherence to be the etiology of abdominal pain in the post-surgical period 26. Furthermore, in our study the adhesive patch did not induce any important inflammatory response, necrosis of mucosa, or intramural fibrosis. In fact, this inflammatory process did not cross the mucosa and upon macroscopic analysis no changes in the serosa portion of the tube, and then no peritoneal adherence was observed. The patch dimension was $0.5 \mathrm{~cm}$ and the reactive area was less than $0.8 \mathrm{~cm}$. This could be an additional advantage in case the obstruction of the tube must be removed. The enlargement of the diameter of the uterine tube close to the adhesive patch may occur because of the increase of the peristaltic waves. Some authors have shown similar results using rabbits in short (30 days) or long-time observations (180 days) 27 being possibly handicapped by the fact that the small dimensions of the tubes in these studies made it difficult to readily perform adherence analyses. Conversely, the tubes in sheep are very similar to those in humans 28 allowing us to compare the results from a clinical standpoint.

\section{Conclusion}

The hysteroscopic insertion of cyanoacrylate in the uterine tube lumen of sheep was effective to obstruct the uterine tube and to promote the sterilization.

\section{References}

1. Available from http://www.engenderhealth.org/news/ newsreleases/020523.html. [Accessed June 07, 2007].

2. Hastings-Tolsma M, Nodine P, Teal SB. Essure: hysteroscopic sterilization. J Midwifery Women Health. 2006; 51:510-4.

3. Minella LS. Aspectos positivos e negativos da esterilização tubária do ponto de vista de mulheres esterilizadas. Cad Saúde Pública. 1998; 14:S69-S79.

4. Vieira EM. O arrependimento após a esterilização feminina. Cad Saúde Pública. 1998; 14:S59-S68.

5. Berquó E, Cavenaghi S. Direitos reprodutivos de mulheres e homens face à nova legislação brasileira sobre esterilização voluntária. Cad Saúde Pública. 2003; 19:S441-53.

6. Kerin JF, Carignan CS, Cher D. The safety and effectiveness of a new hysteroscopic method for permanent birth control: results of the first Essure pbc clinical study. Aust N Z J Obstet Gynaecol. 2001; 41:364-70.

7. MacKay AP, Kieke BA, Koonin LM, Beattie K. Tubal sterilization in the United States, 1994-1996. Fam Plann Perspect. 2001; 33:161-65.

8. Cooper JMJ; Carignan CS; Cher D; Kerin JF. Microinsert nonincisional hysteroscopic sterilization. Obstet Gynecol. 2003; 102:59-67. 
9. Robinson DC, Stewart SK, Reitan RE, Gist RS, Jones GN. Laparoscopic Pomeroy tubal ligation: a comparison with tubal cauterization in a teaching hospital. J Reprod Med. 2004; 49:717-20.

10. Ubeda A, Labastida R, Dexeus S. Essure: a new device for hysteroscopic tubal sterilization in an outpatient setting. Fertil Steril. 2004;82:196-99.

11. Kohaut BA, Musselman BL, Ramos LS, Kaunitz AM. Randomized trial to compare perioperative outcomes of Filshie clip vs. Pomeroy technique for postpartum and intraoperative cesarean tubal sterilization: a pilot study. Contraception. 2004; 69:267-70.

12. Cagirici U, Cetin Y, Cakan A, Samancilar O, Veral A, Askar FZ. Experimental use of N-butyl cyanoacrylate tissue adhesive on lung parenchyma after pulmonary resection. Thorac Cardiovasc Surg. 2007;55:180-1.

13. Matsumoto A, Takimoto K, Yamauchi Y, Kuchide M, Takemura T. Limitations of cyanoacrylate injection in the treatment of gastric fundal varices. Endoscopy. 2004; 36:925.

14. Muto G, D’Urso L, Castelli E, Formiconi A, Bardari F. Cyanoacrylic glue: a minimally invasive nonsurgical first line approach for the treatment of some urinary fistulas. J Urol. 2005; 174:2239-43.

15. Shuber J. Transcervical sterilization with use of methyl 2-cyanoacrylate and a newer delivery system (the FEMCEPT device). Am J Obstet Gynecol. 1989; 160:887-9.

16. Pelage JP, Herbreteau D, Paillon JF, Murray JM, Rymer R, Garance P. Selective salpingography and fallopian tubal occlusion with n-butyl-2-cyanoacrylate: report of two cases. Radiology. 1998; 207:809-12.

17. Neuwirth RS, Richart RM, Bolduc LR, Krall RE. Trials with the FEMCEPT method of female sterilization and experience with radiopaque methylcyanoacrylate. Am J Obstet Gynecol. 1983; 145:948-54.

18. Guzman-Serani R, Rosa G, Cole LP. Evaluation of two applications of methylcyanoacrylate for female sterilization. Adv Contracept. 1986; 2:91-5.
19. Richart RM, Neuwirth RS, Goldsmith A, Edelman DA. Intrauterine administration of methyl cyanoacrylate as an outpatient method of permanent female sterilization. Am J Obstet Gynecol. 1987; 156:981-7.

20. Intaraprasert S, Chaturachinda K. Female sterilization in Thailand: past, present and future. J Med Assoc Thai. 1993; 76:2-10.

21. Levie MD, Chudnoff SG. Office hysteroscopic sterilization compared with laparoscopic sterilization: a critical cost analysis. J Minim Inv Gynecol. 2005; $12: 318-22$.

22. Abbott J. Transcervical sterilization. Best Pract Res Clin Obstet Gynaecol. 2005; 19:743-56.

23. Berkey GS, Nelson R, Zuckerman AM, Dillehay D, Cope C. Sterilization with methyl cyanoacrylateinduced fallopian tube oclusion from a nonsurgical transvaginal approach in rabbits. JVIR. 1995; 6:669-74.

24. Sonmez AS, Arub I, Dunn RC, Kaufman RH, Chuong CJ. Sterilization with fibrin sealant in a rabbit uterine horn model. Am J Obstet Gynecol. 1997; 177:573-8.

25. Shaw DG, Bowles CM, Raja K, Lishman AW. Transvaginal oocyte retrieval and subsequent in vitro production of embryos from a cow involuntarily culled. J S Afr Vet Assoc. 1999; 70:130-1.

26. Srinivasan R, Greenbaum DS. Chronic abdominal wall pain: a frequently overlooked problem. Practical approach to diagnosis and management. Am J Gastroenterol. 2002; 97:824-30.

27. Rivoire HC, Fagundes DJ, Taha MO, Novo NF, Juliano Y. Esterilização tubária com adesivo cirúrgico sintético: estudo experimental. Rev Col Bras Cir. 2003; 30:337-43.

28. Noronha PB, Borelli V, Barbosa J. Estudo morfológico dos componentes do pedículo ovariano de ovelha. Rev Inst Cienc Saúde. 2003; 21:351-6.

\section{Correspondence:}

Sergio Bigolin

Rua Adolfo Hofstaetter,49 Loteamento Shmidt

99700-000 Erechim - RS Brazil

Phone: (55 54)332-13-564

bigolin@itake.net.br
Conflict of interest: none Financial source: none

Received: March 15, 2007 Review: May 18, 2007

Accepted: June 20, 2007

\section{How to cite this article}

Bigolin S, Fagundes DJ, Rivoire HC, Fagundes ATN, Simões R, Simões MJ. Hysteroscopic sterilization with occlusion of sheep uterine tube using n-butyl-2-cyanoacrylate adhesive. Acta Cir Bras. [serial on the Internet] 2007 Sept-Oct;22(5). Available from URL: http://www.scielo.br/acb 